\title{
A MONTENEGRÓI KOALÍCIÓ EGY ÉVE
}

\section{The first year of the governing coalition in Montenegro}

\section{Tóth László ${ }^{1}$}

\begin{abstract}
Absztrakt: 2020 nyarán földrengésszerű változások következtek be
\end{abstract} Montenegró politikai életében. A legkisebb jugoszláv utódállam rendszerváltozás utáni történelmében először alakult kormány a politikai rendszert addig domináló Szocialisták Demokratikus Pártja (DPS) nélkül. Az Európában szinte példátlan, három évtizedes megszakítás nélküli kormányzás után mindenképpen innovatív formátumú kormány jött létre a balkáni országban, ami önmagában is érdemessé teszi a vizsgálatra. A sok komponensből álló, koalíciós kormány számára jelentős kihívást jelentett egyrészt a kormányzati tapasztalat szinte teljes hiánya, másrészt az új koalíció rendkívüli heterogenitása. A sorsfordító választás óta eltelt egy év viharos periódus volt, ami igazolta a kabinettel kapcsolatos, már a megalakulásakor jelentkező félelmeket. Az identitás, nemzetiség, illetve vallás tekintetében rendkívül megosztott országban komoly konfliktusokat generált az alapvetően szerbpárti kormánykoalíció tevékenysége, mindazonáltal maga a kabinet is rendkívül instabilnak bizonyult. Utóbbit mutatja az a tény is, több hónap telt el a választás, és az új, Zdravko Krivokapić vezette kormány beiktatása között, ráadásul a kabinet már alig több mint fél évvel hivatalba lépése után a bukás szélére sodródott.

Jelen tanulmány célja, hogy bemutassa a kettôs szorításban működő montenegrói kormány létrejöttének körülményeit, azt a feltételrendszert, amelyben működnie szükséges, továbbá, hogy mindezek a tényezôk milyen befolyással bírnak mind ezen koalíciós kormány stabilitására, mind pedig az ország általános értelemben vett társadalmi-politikai stabilitására. A

1 Tóth László, ELTE ÁJK Doktori Iskola (abszolutórium). Munkahely: Tokaj-Hegyalja Egyetem, Lorántffy Intézet, Társadalomtudományi Tanszék. Kutatási területe: kormányzati stabilitás, Kelet-Közép-Európa politikai rendszerei.

ORCID: https://orcid.org/0000-0002-3605-9958

A szerző további munkásságát lásd a Magyar Tudományos Művek Tárában: https: $/ / \mathrm{m} 2 . \mathrm{mtmt}$. hu $/$ gui2 $/$ ?type $=$ authors\&mode $=$ browse\&sel $=10057218$ 
tanulmány a kormányzati stabilitás kutatásának elméleti keretrendszere alapján vizsgálja a balkáni ország kormányának helyzetét.

Kulcsszavak: Montenegró, stabilitás, megosztott ország, sokpárti koalíció, kormányválság

Abstract: In the summer of 2020, earthquake-like changes took place in the political life of Montenegro. For the first time in the history of the smallest Yugoslav successor state after the regime change, a government was formed without the Democratic Party (DPS) of the Socialists, which had dominated the political system until then. After an almost unprecedented three-decade period of uninterrupted governance in Europe, an innovative format of government has definitely emerged in the Balkan country, which in itself makes it worthy of investigation. A significant challenge for a multicomponent coalition government was the almost complete lack of government experience on the one hand, and the extreme heterogeneity of the new coalition on the other. One year since the turnaround election was a turbulent period, which confirmed the fears of the cabinet that had already emerged when it was formed. In a highly divided country in terms of identity, nationality and religion, the activities of the fundamentally proSerb government coalition generated serious conflicts, however, the cabinet itself proved to be extremely unstable. The latter is also shown by the fact that several months have passed between the election and the inauguration of the new government led by Zdravko Krivokapić, and the cabinet has drifted to the brink of collapse just over half a year after taking office.

The aim of the present study is to present the circumstances of the formation of the Montenegrin government, the conditions under which it needs to operate, and the impact of all these factors on both the stability of this coalition government and the country's socio-political stability in general. The paper examines the situation of the government of the Balkan country on the basis of the theoretical framework of government stability research.

Keywords: Montenegro, stability, divided country, multiparty government, government crisis 


\section{BEVEZETÉS}

2020. augusztus 30-án egy közel harminc éves periódus zárult le Montenegróban. A legkisebb jugoszláv utódállam rendszerváltozás utáni történelmében első alkalommal bukott meg az ottani kommunista utódpártnak is tekinthető Szocialisták Demokratikus Pártja (rövidítve: DPS), és ennek következtében alakult meg az első olyan kormány, amely ezen erő részvétele nélkül múködik. A több szempontból rendkívül megosztottnak tekinthető országban a sokpárti koalíciós Krivokapić-kormány nehéz helyzetben kezdhette meg múködését. Mind a külső tényezők (az ország megosztottsága, a harminc éven át hatalmon levô elitek beágyazottsága), mind a belső viták, nézetkülönbségek (koalíció széttagoltsága, pártok eltérő célrendszerei) a kormány instabilitását vetítették előre. A tanulmány bemutatja a montenegrói politikai rendszer alapvonalait, a szituációt, amelyben a kormány megalakulhatott, illetve a fentebb idézett külső és belső destabilizáló tényezőket. A dolgozat az egy év után levonható következtetések bemutatásával zárul.

\section{A MONTENEGRÓI DEMOKRÁCIA HELYZETE - ELMÉLETI BEVEZETŐ ÉS TÖRTÉNELMI VISSZATEKINTŐ}

A kormányzatok helyzetére, stabilitására a parlamentáris rendszerekkel bíró országok esetében a következő tényezők vannak leginkább hatással: intézményes viszonyok, a választási rendszer, a pártrendszer jellegzetességei. ${ }^{2}$

Montenegró a többi kelet-közép-európai és ezen belül nyugat-balkáni állammal ${ }^{3}$ egyetemben az 1980-as és 1990-es évek fordulóján vált kommunista egypártrendszerű rezsimből többpárti parlamentáris

\footnotetext{
2 TóTH, 2020. 258-261.o.

3 Kelet-Közép-Európán a dolgozat azon államok összességét érti, amelyek a nyolcvanas évek végéig államszocialista rendszerben múködtek, majd1989/90 folyamán demokratizálódtak. Többféle megközelítés létezik a szakirodalomban, itt a Baltikum államai, a „Visegrádi Négyek”, az egykori Jugoszlávia utódállamai, valamint Románia, Bulgária és Albánia értendők a körbe. Nyugat-Balkánon a jugoszláv utódállamok és Albánia értendők, így ez itt egy részhalmazát képezik az előbbinek. A tanulmány tehát Kelet-KözépEurópa tágabb megközelítését alkalmazza.
} 
demokráciává. ${ }^{4}$ A helyzetét a többi régiós országhoz - és a többi jugoszláv utódállamhoz - képest bonyolította, hogy csak 2006-ban lett teljesen független állam, addig Szerbiával egy államközösséget alkotott, a (harmadik) Jugoszlávia, majd 2003 után a Szerbia-Montenegró névre hallgató föderáció részeként. ${ }^{5}$ Mindazonáltal, önálló montenegrói politikai rendszerről már a kilencvenes évek óta beszélhetünk, az ország belső fejlődése lényegében már a kilencvenes évek közepe óta önálló utat követett. ${ }^{6}$

Az 1990-es évek közepe óta lényegében egyirányúnak tekinthető önállósodási folyamat 2006 tavaszán, a függetlenségi népszavazás által teljesedett be. Az immáron független állam alkotmányát 2007-ben fogadták el, az addigi tagköztársasági szintű intézmények akkor már a független állam legfontosabb szervei lettek.

A montenegrói államiság mindazonáltal több száz éves múltra tekint vissza, ez az oszmán hódítás korszakától egészen a XIX. század második feléig egy autonóm fejedelemség formátumában múködött. A teljes nemzeti függetlenség időszaka 1878-tól 1918-ig, a délszláv államba való inkorporálásig tartott. ${ }^{7}$ Utóbbi máig vita tárgyát képezi, amelyben az ország különböző identitással rendelkező csoportjai feszülnek egymásnak. A 2020ban komoly tiltakozáshullámot kiváltott egyházügyi törvény értelmezésével kapcsolatos radikálisan eltérő álláspontok is ide vezethetők vissza.

\section{A KORMÁNY HELYZETÉT BEFOLYÁSOLÓ TÉNYEZŐK}

\subsection{A kormány helyzetét befolyásoló tényezők I. - Az intézményes viszonyok}

A montenegrói intézményrendszer kialakulásának gyökerei a titói Jugoszlávia idejére vezethetôk vissza. A nyolcvanas évek végén az 1974-es jugoszláv alkotmány határozta meg a köztársasági intézményrendszert. A többpártrendszer kialakulása, illetve a demokratikus fordulat is ezen intézményi keretek között ment végbe, a legkomolyabb változás az

\footnotetext{
${ }^{4}$ Bieber, 2003., KovaceVic, 2007.

${ }^{5}$ DRINÓCZI, 2007.

${ }^{6}$ A 2000-es szövetségi szintű választásokat a montenegrói kormánypártok már bojkottálták, a DPS és szövetségesei ekkor már kivonultak a szövetségi szintű intézményekből. Lásd: HAUKAAS, 2013. 571-572.o.

${ }^{7}$ Lásd: DRINÓCZI, 2007. 626.o.
} 
egyszemélyi (tagköztársasági) elnöki intézmény létrehozása volt 1990-ben. ${ }^{8}$ Montenegró egészen a 2006-os függetlenségi népszavazásig de jure tagköztársasági szintű politikai intézményrendszert mûködtetett, jóllehet, a kilencvenes évektől egyre érezhetőbb volt a törekvés a Szerbiától való elszakadásra, és a gyakorlatban is megnőtt a kisebbik államalkotó rész önállósága.

Montenegró parlamentáris köztársaság, az államfő súlya és szerepe azonban jelentősebb a parlamentáris rendszerek ideáltipikusnak tekinthető alapvetően reprezentatív szerepköréhez képest. ${ }^{9}$

A montenegrói elnök komolyabb súlyát adja egyrészt a közvetlen választás ténye, ami jelentős legitimitást ad a poszt birtokosának. Az államfő súlyát növelő másik tényező a tisztséget betöltő személy politikai befolyása. Utóbbi különösen a posztot több cikluson (1998-2002, 2018-) keresztül betöltő Milo Đukanović mandátuma alatt érvényesül, aki kétségtelenül az elmúlt három évtized legnagyobb befolyással bíró montenegrói vezetője.

A montenegrói államfő befolyását potenciálisan növelő tényező az instabil pártrendszerekkel jellemezhető országok egy jellegzetes sajátossága. Azon országokban, ahol a töredezett pártrendszerek következtében nem, vagy nem mindig áll fönn stabil kormányzati többség, általában nagyobb mozgástere van saját politikai céljai érvényesítésében az államfőnek. ${ }^{10}$

A kormány pozíciója tekintetében egyértelműen a parlamentáris rendszerek logikája érvényesül, a kabinet kizárólag a négy éves mandátumra választott egykamarás törvényhozásnak felelős. Alapvetően a törvényhozáshoz képest gyenge kormányról beszélhetünk, mivel nemcsak a kormányfő személyérôl kell szavaznia a parlamentnek, hanem a kormány tagjairól is. A miniszterelnököt a köztársasági elnök javaslatára választja a törvényhozás, a többi kormánytag személyére a kormányfö-jelölt tesz javaslatot, 30 napon belül. ${ }^{11}$ A kormányprogramról, valamint a kormány névsoráról egyazon szavazáson dönt a parlament. ${ }^{12}$ A kormányfö elleni bizalmatlansági indítvány (melynek sikere esetén az egész kormánynak távoznia kell) benyújtására 27 képviselő (a testület tagjainak egyharmada)

\footnotetext{
${ }^{8}$ BieBER, 2003. 16-17.o., HAUKAAs, 2013. 567-568.o.

9 Bizonyos források gyenge elnökkel bíró félelnöki rendszernek tekintik. A kormány parlament előtti felelőssége miatt indokolható a parlamentáris kategóriába sorolás. Lásd: Vujović-TOMOVIĆ, 2019. 119.o.

10 A szerző nyilvános vitára bocsátás előtt álló disszertációjának eredményei alapján.

11 Montenegro's Constitution of 2007, Art. 103.

12 Montenegro's Constitution of 2007, Art. 103.
} 
jogosult, elfogadásához a képviselők abszolút többsége szükséges. ${ }^{13}$ A parlament idő előtti feloszlatása akkor kerül sor, ha 90 napon túl sem képes megválasztani az államfó által jelölt miniszterelnököt, ez esetben a köztársasági elnök rendeli el a feloszlatást. ${ }^{14}$ Feloszlatható továbbá a parlament a kormány kezdeményezésére, amennyiben nem képes ellátni alkotmányban rögzített feladatát. Utóbbi esetben a házelnökkel, illetve a törvényhozási frakciókkal való egyeztetés után mondható ki a feloszlatás. ${ }^{15}$

A montenegrói választási rendszer kedvez az instabil pártviszonyok kialakulásának. Arányos, zárt listás rendszer, ahol viszonylag alacsony (3\%) a jogi (explicit) küszöb. Az ország soknemzetiségű voltára tekintettel a nemzeti kisebbségek által állított listák számára ez a küszöb nem vonatkozik, ők így amennyiben elérik az egy képviselő bejuttatásához elegendő szavazatmennyiséget, mandátumhoz juthatnak. ${ }^{16}$

Az arányos, alacsony küszöbbel rendelkező választási rendszer illetve a kedvezményes nemzetiségi mandátumok - következtében rendre koalíciós kényszer áll fenn Montenegróban, ami potenciálisan az instabilitást erősítheti. A Szocialisták Demokratikus Pártja (rövidítve: DPS) dominanciája ezt 2020 előtt részben árnyalni tudta, igaz, az előrehozott választások viszonylag magas száma ${ }^{17}$ azt jelentette, hogy nem mindig állt rendelkezésre a megfelelő törvényhozási többség még számukra sem.

\subsection{A kormány helyzetét befolyásoló tényezők II. - Törésvonalak, pártrendszer}

A montenegrói pártrendszer alapvonalaira kétféle tényezőkör bír jelentős hatással. Az egyik az országban a politikai tagozódást meghatározó törésvonalak köre, a másik pedig a pártok mint szervezetek stabilitása.

Montenegró rendkívül megosztott országnak tekinthetô, ez a pártpolitikai törésvonalakban is lecsapódik. A Lipset-Rokkan szerzőpáros

\footnotetext{
13 Montenegro's Constitution of 2007, Art. 107.

14 Montenegro's Constitution OF 2007, Art. 92.

15 Montenegro's Constitution of 2007, Art. 92.

16 SZABÓ, 2021. 136.o.

17 1998-ban, 2001-ben, 2002-ben, 2009-ben, és 2012-ben került sor idő előtti választásra. 1992-ben a két tagállammal létrejövő Jugoszláv Szövetségi Köztársaság föderális választásaival egyidőben került sor tagállami választásra is, így azt nem számítjuk ide. A ciklus teljes kitöltése utáni választásokra került sor 1996-ban, 2006-ban, 2016-ban, illetve 2020-ban.
} 
nevéhez füződő törésvonal-kategóriák ${ }^{18}$ közül az országban meghatározó a nemzeti függetlenséggel kapcsolatos törésvonal. ${ }^{19}$ Ez Montenegró esetében komplex törésvonal, mivel van etnikai komponense is, a pártversenyben is lecsapódó szembenállás azonban részben túlmutat a közvetlen etnikai megoszláson. A nagyjából 620,000 fôs lakosságú országban a relatív többséget (40-45\%) a montenegrói nemzetiség adja. A társadalom egy jelentős szegmense (a lakosság egynegyed és egyharmad közötti része) magát szerbnek tekinti, montenegrói szerb identitású. Rajtuk kívül a bosnyák, az albán, illetve az úgynevezett muzulmán kisebbség súlya lényegesebb, utóbbiak egy speciálisan Montenegróban elismert etnikai csoport tagjai. ${ }^{20} \mathrm{~A}$ társadalom montenegrói identitással rendelkező része az ország függetlenségének, és a Szerbiától való megkülönböztetésnek híve. A szerb tudatú társadalmi szegmensek a Szerbiával való egyesülés, vagy legalábbis a szoros együttmúködés hívei. Ők Montenegrót egy tágabb „szerb világ” részeként tudják elképzelni, ők a montenegrói történelemre is mint a szerb történelem egy részére, a montenegrói nyelvre is mint egy szerb dialektusra tekintenek. A szerb identitásúak részéről az 1918-as csatlakozás a délszláv egységállamhoz egy természetes integráció része, míg a montenegrói tudatúak megszállásként értékelik azt. A lakosság ilyen megosztottsága mögött főként a határok a történelemben gyakori változásai, valamint a jelentősebb mértékű, főleg 1918 utáni népmozgások állnak.

A nemzeti-etnikai törésvonal mellett legalább ennyire fontos a vallási törésvonal. Az albán, illetve muzulmán néven említett kisebbségek kivételével az ország lakossága az ortodox vallást követi. Ennek legfontosabb intézménye a Szerb Pravoszláv Egyház (rövidítve: SPC) montenegrói ága, amely tulajdonképpen a Belgrád-központú szerb egyház része. Ez általános elismertségnek örvend az ortodox egyházak körében. ${ }^{21}$

Ezzel szemben áll a Montenegrói Pravoszláv Egyház (rövidítve: CPC), melynek létrehozására a rendszerváltás után történt kísérlet, a függetlenségpárti kormányzatok komoly támogatásban részesítették a nemzeti identitást is erősíteni hivatott egyházat. ${ }^{22} \mathrm{~A} z \mathrm{SPC}$-vel szemben ez az

\footnotetext{
18 Lásd: LIPSET-ROKKAN, 1967.

${ }^{19}$ HaUkAAs, 2013. 567.o.

${ }^{20}$ Az ő esetükben a muzulmán jelzőnek nem csak vallási, hanem etnikai vonatkozása is van. Az etnikai viszonyokkal kapcsolatos adatok forrása: HAUKAAS, 2013. 575.o.

${ }^{21}$ KAJOSEVIĆ, 2021c.

22 European Commisson for Democracy through Law, 2019. 5.o., Kajosević, 2021c.
} 
egyház egyáltalán nem tekinthető elismert egyháznak, így befolyása csak az országra korlátozódik. Történelmi okok következtében így a tradicionálisnak számító SPC hívei közé tartozik a montenegrói identitású lakosság egy jelentős hányada. ${ }^{23} \mathrm{Az}$ SPC a függetlenségpárti erők (mindenekelőtt a DPS, és személyesen Đukanović) álláspontja szerint az ország Szerbia felé való elköteleződését támogatja, szerintük a 2006-ban népszavazáson kivívott függetlenség aláásására törekednek. ${ }^{24}$ Mindazonáltal, mivel az egyébként montenegrói identitással bíró lakosok egy része is az ő hívük, ezért nem elhanyagolható az állam viszonya ehhez az egyházhoz.

Montenegróban a nemzeti, vallási, illetve az ország orientációjával kapcsolatos törésvonalak egymásra rakódnak, ez pedig egy rendkívül polarizált, mélyen megosztott társadalmat - és pártpolitikai szférát - jelent.

A pártok szervezeti háttere - leszámítva a Szocialisták Demokratikus Pártját - gyengének tekinthető. Montenegróban megfigyelhető jelenség a gyakori pártszakadások következtében a pártok szétaprózódása, sok kis párt jelenléte a rendszerben. Ezen pártszakadások jelentôs része kifejezetten személyi természetű ellentétek mentén történik, ez pedig perszonalista, vagy vezetőközpontú (kis) pártok nagyobb számát eredményezi. ${ }^{25}$

A párt-aprózódás következménye, hogy a választásokon általában nem egyedül indulnak a pártok, hanem többtagú koalíciókat alkotva. Ez a DPS-re jellemző a legkevésbé, bár ők is több alkalommal kötöttek már megállapodást kisebb erőkkel. Ezen esetekben a DPS egyértelmúen domináns félnek tekinthető, a pártpolitikai paletta többi szegmensénél több elemből álló és széttagoltabb koalíciók jelennek meg. Nem ritka a többszintű pártkoalíció sem.

A pártrendszer az elmúlt harminc évben mindezen tényezők mellett aszimmetrikus volt, és ez a jelleg a 2020-as választások után sem tűnt el teljesen. Bár vannak források, amelyek predomináns pártrendszerként emlegetik $^{26}$ a montenegróit, ezen kategória szigorú definíciójának nem felel meg. ${ }^{27}$ Mindazonáltal, kivételesnek tekinthető, hogy harminc éven keresztül megkérdőjelezhetetlen vezető pozíciót töltött be ezen erő.

\footnotetext{
${ }^{23}$ KAJOSEVIĆ, 2021c.

${ }^{24}$ KAJOSEVIĆ, 2021c.

25 A montenegrói pártok elaprózódásáról és az új pártok megjelenéséről lásd: STANKOV, 2019., a pártok eredetéről lásd: VuJOVIĆ-TOMOVIĆ, 2019. 122-132.o.

26 Például Vujović-Tomović, 2019.

27 Mivel általában nem tudta egymaga megszerezni a törvényhozási helyek abszolút többségét, csak koalíciós partnerek segítségével tudott megszakítás nélkül kormányozni.
} 
A DPS az egykori Montenegrói Kommunisták Szövetsége (SKCG) jogutódjaként jött létre 1991 júniusában. ${ }^{28}$ Az első többpárti választás 1990 decemberében volt a tagköztársaságban, ott - hasonlóan a másik két ortodox többségü tagállamhoz, Szerbiához és Macedóniához - a kommunista párt tudta megszerezni a többséget. ${ }^{29} \mathrm{Ez}$ a dominancia fennmaradt a következő évtizedekben is, aminek egyik legfontosabb tényezője a párt alkalmazkodóképessége volt. További fontos tényező volt e téren a párt összefonódása a különféle hatalmi pozíciókkal, a hatalomban töltött idő egy idő után visszahatott a párt választási sikereire is.

A DPS vezetőközpontú pártként írható le, harminc éves története összefonódik Milo Đukanović politikai karrierjével. Vagy formális, vagy informális pártvezetőként, kormányfőként, vagy éppen államfőként Đukanović folyamatosan a leginkább meghatározó szereplője nemcsak a Szocialisták Demokratikus Pártjának, hanem az egész montenegrói politikai

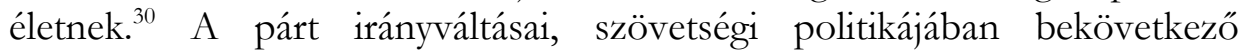
változásai összefüggésben voltak Đukanović személyes stratégiai döntéseivel..$^{31}$

A DPS magát szociáldemokrata pártként definiálja, szerepe azonban túlmutat ezen pártcsalád helyi reprezentálásán. Egyrészt a pártrendszer egyértelmú domináns pártja, kvázi rendszerpárt, ${ }^{32}$ másrészt pedig a kilencvenes évek második felétől kezdve a Szerbiától való eltávolodás, majd a nemzeti függetlenség, majd - ezekkel párhuzamosan - az ország nyugati integrációja iránt elkötelezett, magát a leginkább nyugatpártiként definiáló erő. ${ }^{33}$ Ennek jegyében volt élharcosa a párt (illetve Đukanović) az ország NATO-csatlakozásának, ami 2017-re realizálódott. Utóbbi amellett, hogy geopolitikai konfliktusokat is generált, megosztó témának számít az országban, a társadalom szerb identitású, illetve a Szerbiával szoros kapcsolatokat fenntartani kívánó része ellenezte ezt a lépést, és továbbra is a NATO tagság ellen van. ${ }^{34}$

\footnotetext{
${ }^{28}$ KOMAR-ŽIVKOVIĆ, 2016. 785-786.o.

29 VuKOVIĆ, 2013. 1-2.o.

30 A fent már említett államfói periódusai mellett 1991-1998, 2003-2006, 2008-2010, 20122016 közötti időszakokban töltötte be a miniszterelnöki pozíciót, a DPS-nek 1998 októbere óta folyamatosan elnöke.

31 VuKOVIĆ, 2013. 12-13.o.

32 VukOVIĆ, 2013. 5-12., Vujović-TOMOVIĆ, 2019. 130.o.

33 VukOVić, 2013. 13., HaUkAas, 2013. 579.o.

34 Vujović-Tomović, 2019. 127-128.o.
} 
A DPS ellenzéke a rendszerváltás óta folyamatosan heterogén. Mivel az ellenzék gyenge és fejletlen volt ebben a tagköztársaságban a rendszerváltás előtt, ${ }^{35}$ a kilencvenes években egyrészt nemzeti kisebbségi alapokon szerveződő erők jelentek meg, amiket csekélyebb támogatottságú, különféle ideológiák mentén létrejövő pártok egészítettek ki. A nemzetiségi alapokon szerveződő pártok közül - a szerb identitású lakosság létszámaránya következtében - kiemelendőek a helyi szerbséget képviselő pártok, amelyek tovább tagolhatók stratégiai, vagy személyes eredetű törésvonalak szerint. Ezt a kört nem fedi le teljesen azon erők köre, amelyek ugyan nem a szerb identitású lakosok képviseletét deklarálták fő célként, azonban az ország Szerbiához való szoros kötődését szorgalmazzák. A montenegrói pártrendszerben töréspontot jelentett a Milošević-rezsimhez való viszonyulás (a kisebbik jugoszláv tagköztársaságban a szerb vezető politikájával szembenálló szövetségnek a kilencvenes években tagjai voltak montenegrói, illetve szerb identitású pártok is), ${ }^{36}$ illetve a függetlenség kérdése (itt a deklaráltan szerb lakosságot képviselő pártok és a föderáció fenntartását szorgalmazó többi párt lépett szövetségre a DPS-szel szemben). A személyes okokból bekövetkező pártszakadásokkal együtt ez a többes konfliktusrendszer rendkívül tagolttá tette szervezeti szempontból a DPSszel szembenálló oldalt, mindazonáltal 2020-ra itt is kikristályosodott három nagyobb irányvonal.

A DPS dominanciája generált egyfajta rendszer-törésvonalat is, bár összességében elmondható, hogy 2020-ra a DPS-szel a hatalmi dominancia, illetve a rendszerszintű korrupció miatt szembehelyezkedő erők be tudtak tagozódni a nemzeti-vallási-identitási alapon szerveződő ellenzéki pártok csoportjába. Utóbbiak közül említésre méltó a kétezres években eleinte önállóan próbálkozó PzP, ${ }^{37}$ illetve a 2010-es években felbukkanó URA.

A DPS ellenzékeként funkcionáló csoportok megosztottak az ország orientációjának kérdésében is. Amellett, hogy a NATO-tagságot egyöntetűen elutasítják, az EU-csatlakozás tekintetében eltérő állásponton vannak. A határozottan szerbpárti erők nem, vagy csak fenntartásokkal támogatják az európai integrációs folyamatban való részvételt, míg az új

\footnotetext{
35 BIEBER, 2003. 16-17., KOVACEVIC, 2007. 72-73.o.

${ }^{36}$ HAUKAAS, 2013. 570-572.o.

37 A PzP vezetője, Nebojša Medojević kifejezetten azért ellenezte a függetlenség deklarálását 2006-ban, mert attól tartott, az önálló kis állam Đukanović szövetségesei személyesen irányított országa lesz (HAUKAAS, 2013. 581.o.).
} 
politikát hirdetők, a korrupcióellenes, magukat progresszívnek definiáló csoportok támogatnák azt. ${ }^{38}$

Az egyes kisebb nemzetiségeket képviselő pártok (bosnyák, albán, illetve muzulmán nemzetiség képviseletében fellépő pártok) a DPS szövetségesei voltak az elmúlt harminc év nagyobb részében, különösen az utóbbi periódusokban. ${ }^{39}$

\section{VÁLASZTÁS ÉS KORMÁNYALAKÍTÁS 2020-BAN}

\subsection{A 2020 nyári választás körülményei, a végeredmény magyarázata}

A 2020-as választást megelőző hetek és hónapok legfontosabb eseménysora - a koronavírus-pandémia mellett - az úgynevezett egyházügyi törvény elfogadása, és az akörül kitörő társadalmi szintű tiltakozó mozgalom volt. ${ }^{40} \mathrm{Az}$ egyházügyi törvény leginkább vitatott rendelkezése az volt, hogy az egyes egyházi szervezeteknek igazolniuk kellett, hogy milyen ingatlanokkal rendelkeztek 1918, Montenegró a délszláv egységállamba való inkorporálása előtt. A nyíltan a CPC pozícióit erősíteni kívánó függetlenségpárti kormányzat a törvénymódosítással az SPC álláspontja szerint a szerb egyház ellehetetlenítésére tört, mert a törvény következményeként elveszítené ingatlanai jelentős részét, köztük középkori templomokat, kolostorokat. Mivel sok montenegrói identitású híve is van az SPC-nek, ezért a tiltakozás átlépte az etnikai határokat. ${ }^{41}$

$\mathrm{Az}$ augusztusi választáson az ellenzéki koalíciók alapvetően kétféle narratívával tudtak élni. Egyrészt, sikerrel tudták mozgósítani a szerb identitású lakosságot, illetve azokat, akik ellenezték az egyházügyi törvénymódosítást.

Az ellenzéki erők másik fő narratívája a 30 éve hatalmon levő, korruptnak tekintett DPS elittel, a három évtized alatt kiépült klientúrával való leszámolás volt.

A DPS ellenzéke három tömböt alkotva vett részt a választásokon. A legnagyobb csoport a Montenegró Jövőjéért (ZBCG) nevet viselte. Ennek meghatározó ereje a Demokratikus Front, maga is különböző szerbpárti,

\footnotetext{
38 LAVRELASHVILI, 2020.

39 Vujović-TOMOVIĆ, 2019. 128.o.

40 KaJOSEVIĆ, 2021c.

${ }^{41}$ KAJOSEVIĆ, 2020a.
} 
illetve szerb érdekeket képviselő pártok szövetsége. ${ }^{42}$ Rajtuk kívül a Szocialista Néppárt (SNP) foglal helyet a koalícióban, amely a DPS szakadása által jött létre a kilencvenes évek közepén, a Milošević politikáját támogató csoportból. ${ }^{43}$ Hozzájuk csatlakozott több olyan törpepárt is, melyek egyértelműen szerb orientációjúak. A ZBCG a leginkább szerbpárti tömörülés az ország politikai életében.

A második legnagyobb tömb szintén koalíció, ez a Béke a Mi Nemzetünk (MJNN) nevet viselte. Ennek két tagja jutott mandátumokhoz. A Demokraták 2015-ben szakadtak ki az SNP-ből, ez egy mérsékelten szerbpárti, az EU integrációt támogató konzervatív-liberális erő. A DEMOS névre hallgató szervezet a Demokratikus Frontból vált ki szintén 2015-ben, egy mérsékelt, EU párti jobbközép politikát meghirdetve. ${ }^{44}$

A harmadik ellenzéki tömb az Egyesült Reform Akció (URA) nevü, 2015ben alakult ${ }^{45}$ EU-párti, zöld és liberális értékeket is hangoztató szervezet körül alakult Feketén Fehéren (CnB) koalíció volt.

Részben a járvány hatásainak, részben az egyházügyi törvénymódosítás hatásainak következtében az augusztus 30-án megtartott választás során a korábban ellenzékben levő pártkoalíciók rendkívül szűk, egyfős többségre tettek szert a 81 fős törvényhozásban. A korábbi választásokhoz hasonlóan az első helyet a DPS szerezte meg, azonban mivel ellenzéke egyértelműen többségbe került, kormányt a kisebbségekkel, illetve további potenciális partnerekkel sem volt képes alakítani. A három választási koalíció öt törvényhozási képviselőcsoportot hozott létre. (Önálló frakciót alakított a CnB és az MJNN, szintén önálló frakciót hozott létre a ZBCG szövetségből az SNP. A Demokratikus Frontból külön csoportot alakított a PzP, a legnagyobb kormánypárti frakció pedig a DF többi tagpártjából formált

42 A Demokratikus Front legnagyobb tagszervezete az Új Szerb Demokrácia 2009-ben alakult a különböző, a szerb nemzetiséget képviselni kívánó pártok szövetségéből. A második legnagyobb DF-tag a Mozgalom a változásokért (PzP), a 2000-es évek elején jött létre eleinte antikorrupciós NGO-ként, majd önálló pártként múködött, mielőtt a DF-be tagozódott volna. (HAUKAAS, 2013. 580-581.o., STANKOV, 2019. 177.o.) A harmadik meghatározó csoportja a DF-nek a Demokrata Néppárt (DNP), mely a Szocialista Néppárt 2012-ben kiszakadt jobbszárnyából jött létre (LAVRELASHVILI, 2020.)

${ }^{43}$ HAUKAAS, 2013. 570.o.

44 STANKOV, 2019. 177-180.o.

$45 \mathrm{Az}$ alapítók zöme a korábban szintén progresszív kis pártként múködő Pozitív Montenegró (PCG) pártból távozott, miután annak vezetői a DPS kormányának támogatása mellett döntöttek (STANKOV, 2019. 175-176.o.). 
csoport lett, 16 fóvel. $)^{46}$ Mindennek következtében egy heterogén, sokszereplős koalíciós kormány alakulhatott, a formálisan pártonkívüli, a ZBCG által jelölt Zdravko Krivokapić, a műszaki egyetem professzora vezetésével.

\subsection{A Krivokapić-kormány megalakulása, összetétele, a koalíció működése}

Mivel a korábban ellenzékben szereplő koalíciók mindegyike többszörösen is tagoltnak tekinthető, ezért már eleve nehézkesnek tűnt pártalapú koalíciós kormány létrehozása. A megoldás egy, az aktorok által szakértői kormánynak elnevezett kabinet lett, amelyben mindössze egy miniszterelnök-helyettes tekinthetô a szó szoros értelmében vett pártpolitikusnak. ${ }^{47}$ Politikatudományi értelemben mindazonáltal megkérdőjelezhető, hogy beszélhetünk-e szakértői kabinetről Zdravko Krivokapić kabinetje kapcsán, mivel az összes posztra konkrét pártok (a koalíció tagszervezetei) delegálták a minisztereket, ahogy a kormányfö is a legnagyobb kormánytényező, a leginkább szerbpárti erő, a Demokratikus Front jelöltjeként nyerhette el hivatalát. A későbbiekben ez a felemás összeállítás komoly konfliktusokat eredményezett.

Nem volt gyors és egyszerű folyamat már az új kormány megalakulása sem, hiszen több mint három hónap telt el a sorsfordító választás, illetve a Krivokapić-kormány beiktatása között, mivel utóbbira mindössze december 4-én került sor. ${ }^{48}$

Az új kormány prioritásai között előkelő helyen szerepelt a kormoly tiltakozáshullámot kiváltó egyházügyi törvény megváltoztatása, az SPC státuszának rendezése. ${ }^{49}$ Részben ezzel összefüggésben, a nyíltan szerbpárti erők által dominált kormánykoalíció igyekezett az ország Szerbiához való kötődését erôsíteni (ami a függetlenségi népszavazás, illetve Kosovo függetlenségének a montenegrói kormány általi elismerése óta meglehetősen hűvös volt). ${ }^{50} \mathrm{Ez}$ jelentős konfliktusokat eredményezett, hiszen a korábbi kormánypártok ezt a politikát a függetlenségi vívmányok aláásásával

\footnotetext{
46 További egy fô a függetlenek között foglalt helyet. Az adatok forrása: PARLIAMENT OF MONTENEGRO.

${ }^{47}$ KaJOSEVIĆ, 2020b.

48 Milić, 2020.

${ }^{49}$ RADIO FreE EUROPE, 2020.

${ }^{50}$ HAUKAAS, 2013. 586-587.o.
} 


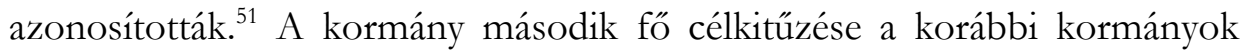
klientúrájának lebontása szerepelt, érintve a közigazgatás és az igazságszolgáltatás szféráját is, ez magától értetődően szintén konfliktusgeneráló törekvés volt. Harmadik problémaként a gazdaság helyzete is a kormány előtt álló kihívásként jelentkezett, különös tekintettel a Bar-Boljare autópálya kínai finanszírozású hitelének bedőlésére, ami komoly veszélyeket hordozott magában. ${ }^{52}$

Mindazonáltal, a kormányzat általában nem állt a helyzet magaslatán a gazdaságpolitika terén, hiszen csak június közepén sikerült a parlamenttel elfogadtatni a folyó évi (!) költségvetést. ${ }^{53}$

\section{KONFLIKTUSOK, DESTABILIZÁLÓ TÉNYEZŐK}

\subsection{Nemzeti megosztottság, harc a korábbi kormányzatok örökségével}

A vártnál lassabban halad az SPC státuszának egyébként prioritást jelentő rendezése, mivel ugyan - titokban - az igazságügy-miniszter bejegyezte a Szerb Pravoszláv Egyházat mint elismert vallási csoportot, ${ }^{54}$ az alapszerződés aláírására ezidáig nem került sor, még Belgrád ez ügyben kifejtett nyomására sem. Mindazonáltal, az egyházügyi kérdés vezetett a koalíció kormányzásának legkomolyabb kríziséhez. Ez a Szerb Egyház Montenegrói-tengermelléki metropolitájának beiktatásán következett be 2021. szeptember 5-én, Cetinjében, az ország történelmi fővárosában. A beiktatás helyszíne ellen már hónapokkal korábban tiltakoztak függetlenségpárti csoportok és a CPC vezetői (mondván ez sérti a montenegrói nemzeti érzéseket), a helyszínen kirobbant tiltakozáshullám súlyos összecsapásokba torkollott. ${ }^{55}$ A kormány puccskísérletről, az ellenzék rendőri erőszakról beszélt.

A harminc éven át hatalmon levő DPS által létrehozott klientúra ellen több fronton intézett támadást az új kormánytöbbség. Egyik eleme a harcnak a köztisztviselők lecserélése volt. Ez a minisztériumi (és egyéb

\footnotetext{
${ }^{51}$ LIKA, 2021.

52 BRÜCKNER, 2021.

${ }^{53}$ Koseva, 2021.

${ }^{54}$ CDM, 2021.

55 BBC, 2021., DW, 2021.
} 
közigazgatási) pozíciókban dolgozók újra-pályáztatásával indult, de egészen az iskolaigazgatók szintjéig eljutott. ${ }^{56}$

A másik komoly front az igazságszolgáltatás rendszerében nyilt. A legnagyobb vihart e téren a kiemelt, korrupciós ügyekre szakosodott Különleges Államügyészséget, illetve a Főállamügyészséget átalakítani szándékozó, azok vezetőinek elmozdítását is eredményező törvényjavaslat keltette 2021 tavaszán. Ezt, mivel növelné a politikai befolyást az ügyészség személyi állományának kiválasztása során, beterjesztése után a Velencei Bizottság is komoly bírálatokkal illette. ${ }^{57}$ A koalíció mögött álló pártok egy részének alapvető jelentőségű volt a javaslat, hiszen ennek segítségével próbálták elérni Milivoje Katnić Különleges Főállamügyész leváltását, aki kulcsszerepet játszott a 2016-os, egyes jelenlegi kormánytényezők részvételével lezajlott puccskísérlet vezetőinek elítélésében. ${ }^{58} \mathrm{~A}$ reguláris Főállamügyészség vezetője, Ivica Stanković 2021 június elején több kollégájával együtt távozott hivatalából. ${ }^{59}$

További konfrontatív lépés volt az állampolgársági törvény megváltoztatása, amely lépés - bírálói szerint - kedvez az országban élő, oda települt - főként szerb identitású, vagy szimpátiájú - személyeknek, kedvezôtlenül érinti azonban - a túlnyomó részben montenegrói identitású, így jelentős mértékben a korábbi, függetlenség,- és nyugatpárti kormánnyal szimpatizáló - nyugaton élő diaszpóra tagjait. Előbbi csoport nagyjából 35, utóbbi 40 ezer főt számlál az összesen hatszázezres országban. ${ }^{60}$

A korábbi kormányzatok örökségével való leszámolás legfontosabb célpontja Milo Đukanović köztársasági elnök. Az immáron legnagyobb ellenzéki párt, a DPS pártelnöki pozícióját is betöltő köztársasági elnökkel lényegében már a kormányzás első hetei óta folyamatosak a verbális összetűzések, a kormánytöbbség, és az államfő közötti viszony töréspontját a szeptember eleji összecsapások hozták el, amelyeket követően a kormánykoalíció pártjai az alkotmány megsértésére hivatkozva kezdeményezték Đukanović hivatalából való elmozdítását. ${ }^{61}$

A kormánykoalíció működésének egy éve során tehát több szinten is komoly konfliktusokat generált, amelyek az ország korábban is meglevő

\footnotetext{
${ }^{56}$ KALUĐEROVIĆ, 2021.

${ }^{57}$ EWB, 2021.

58 KAJOSEVIĆ, 2021a.

${ }^{59}$ KaJosević, 2021d.

${ }^{60}$ KAJOSEVIĆ, 2021b.

${ }^{61}$ RTCG, 2021.
} 
nemzeti, vallási, és politikai megosztottságát tovább mélyítették. E téren a fentiek alapján meglehetôsen határozott volt a kormányzat (illetve a mögötte álló törvényhozási frakciók) politikája, azonban összességében egy belső feszültségekkel nagyban terhelt, más területeken lassú (lásd a folyó évi költségvetés júniusi elfogadását!), nem túl hatékony politikát folytató kormányzás képe rajzolódott ki.

\subsection{A koalíció belső problémái}

A konstrukció, amit szakértői kormánynak neveznek, kiváltotta az egyes fajsúlyos szereplők elégedetlenségét. Különösen a legnagyobb erőnek tekinthető Demokratikus Front vélekedett úgy, hogy súlyához képest kevés beleszólást kap a kormányzati politikába. A koalíciós erők nehezményezték továbbá azt, hogy a kormányzat - véleményük szerint - túlságosan lassan halad a megelőző harminc év következményeinek felszámolásában. ${ }^{62}$

A kormánypártok közötti erőfelmérésre alkalmat adó események voltak a 2021. első félévében megtartott helyhatósági választások. Ezek enyhe támogatottság-eltolódást mutattak a Demokratikus Front felől mérsékeltebb kormányzati erők (főként az MJNN legnagyobb erejét jelentő Demokraták) irányába. ${ }^{63}$

A koalíció júniusi felbomlását közvetlenül az igazságügy-miniszter menesztése váltotta ki. Vladimir Leposavić - aki a Demokratikus Front pártonkívüli jelöltjeként foglalhatta el pozícióját - már az igazságügyi reformtervezetek miatt komoly bírálat alatt állt, a menesztésére a közvetlen okot azonban az a kijelentése jelentette, melyben megkérdőjelezte az 1995ös srebrenicai vérengzés valóságosságát. ${ }^{64} \mathrm{Ez}$ nemcsak a nemzetközi partnerek számára volt bizonyult elfogadhatatlannak, hanem a kormány mérsékeltebb erőinek és Krivokapić miniszterelnöknek is. A tárcavezető ellenzéki segítséggel megszavazott leváltását követően a Demokratikus Front megvonta támogatását a miniszterelnöktől, a törvényhozás munkáját pedig ettôl fogva - bizonyos stratégiai jelentőségű ügyeket leszámítva bojkottálta. ${ }^{65}$ Június óta tehát bizonytalan a kormány további sorsa. A miniszterelnök nyitott lenne a kormány átalakítására, pártpolitikus személyiségek miniszteri pozícióhoz juttatására, a Demokratikus Front

\footnotetext{
${ }^{62}$ Kajosević, $2021 \mathrm{f}$.

${ }^{63}$ Az eredményekről lásd: RADIO SLOBODNA EvROPA, 2021.

${ }^{64}$ KAJOSEVIĆ, 2021e.

${ }^{65}$ KaJOSEVIĆ, 2021e.
} 
azonban ragaszkodni látszik Krivokapić távozásához. A legalább négy hónapon keresztül tartó folyamatos kormányválság árnyékolta be így a koalíció választási győzelmének egy éves évfordulóját is.

\section{KONKLÚZIÓ}

Kelet-Közép-Európa, illetve azon belül a Nyugat-Balkán országai meglehetôsen vegyes mintázatot mutatnak a kormányzati stabilitás kapcsán. Montenegró mindazonáltal unikális volt a stabilitás egy dimenziójának tekintetében, a ciklusokon átívelő stabilitásban. A többpártrendszer 1990-es bevezetése óta 2020 nyaráig egyetlen egy erő, a posztkommunista utódpárt, a Szocialisták Demokratikus Pártja uralta a politikai palettát, az időszakban folyamatosan kormányon volt, és ez a párt delegálta az ország legfontosabb politikai tisztségviselőit. A megszakítás nélküli kormányzás jelensége mögött azonban egy megosztott ország képe rajzolódott ki, amely elemi erôvel tört felszínre a 2020-as évben esedékes választást megelőzően, majd a voksolás után létrejött új kormány tevékenysége kapcsán.

2020 augusztusa után a korábban legalábbis a felszínen stabilnak mutatkozó országban az instabilitás vált általánossá. Az instabilitás, mely az azóta eltelt egy éven belül a kormány bukását is kézzelfogható közelségbe hozta, több tényező kölcsönhatásának következménye. Az ország politikai intézményrendszerének jellegzetességei (kormány-törvényhozás viszonyrendszer, az államfő szerepe, választási rendszer) alapvetően kedveznek az instabilabb kormányzatok létrejöttének. Ezek hatása - mely a korábbi egypárti dominancia alatt kevésbé volt feltűnő - a korábbi ellenzékből alakuló széles koalíció esetében hatványozottan érvényesül.

Szintén az instabilitást erősíti az ország pártstruktúrájának két jellegzetessége. Az egyik, a vallási-etnikai-identitásbeli törésvonal dominanciája, amely polarizálttá tette a politikai életet, illetve több, egymással másban egyet nem értő szervezetet kényszerített koalícióba. A másik destabilizáló tényező a pártrendszer széttagoltsága, az egymással a koncepcionális eltérések mellett személyi ellentétek mentén is rivalizáló pártok magas száma.

Az új kormány (illetve a mögötte álló pártkoalíció) tevékenysége önmagában is az ország destabilizálódásához járult hozzá. Egyik oldalról az országot megosztott törésvonal további mélyülését eredményezte az egyházakkal kapcsolatos politikája, illetve a korábbi kormányerők reprezentánsaival való szembenállása. A másik oldalról az egy fős parlamenti 
többséggel rendelkező kormány pozíciója is veszélybe került, a mögötte álló pártok megosztottsága miatt.

A montenegrói politikai rendszer fenti két dimenzió mentén történő destabilizálódása hosszabb távra is instabil periódust vetít előre. Az elmúlt egy-másfél éves időszak eseményei demonstrálták, hogy egy társadalmilag megosztott, törésvonalakkal szabdalt ország esetében a stabilitás illúziója könnyen megdőlhet, és a szétfeszítő erôk válnak dominánssá és láthatóvá. Montenegró elmúlt periódusa arra szolgáltat kiváló példát, amikor az egyes stabilitást befolyásoló tényezôk miként erôsítik föl egymás hatását.

\section{FELHASZNÁLT IRODALOM}

\section{Könyvek, tanulmányok}

BIEBER, FLORIAN (2003): Montenegrin politics since the disintegration of Yugoslavia. In Florian Bieber (ed.) Montenegro in Transition: Problems of Identity and Statehood, Nomos Verlagsgesellschaft, Baden-Baden pp. 11-42

Drinóczi TímEA (2007): Montenegró. In Chronowski Nóra-Drinóczi Tímea (szerk.) Európai Kormányformák Rendsz̧ertana Budapest, HVGORAC., 626-640.

European Commisson for Democracy through Law (2019): Draft Opinion on the Draft Law on Freedom of Religion or Beliefs and Legal Status of Religious Communities. Opinion No. 953 / 2019, Strasbourg, 7 June 2019 HAukAAS, JAN O. (2013): Montenegro. In Sten Berglund, Joakim Ekman, Kevin Deegan-Krause, Terje Knutsen (eds.) The Handbook of Political Change in Eastern Europe. Edward Elgar Cheltenham, UK Northampton, MA, USA, 3rd edition, pp. 567-606

Komar, Olivera, SLaven Živković (2016): Montenegro: A Democracy without Alternations. East European Politics and Societies and Cultures, Volume: 30 issue: 4, pp. 785-804

Kovacevic, FiLIP (2007): Montenegro and the Politics of Postcommunist

Transition: 1990 to 2006. Mediterranean Quarterly 18(3) pp. 72-93

Lavrelashvili, TeOna (2020): Party Passport: Montenegro. European Party Monitor, Konrad Adenauer Stiftung, Brussels/Leuven, 19 October, 2020, 9 p.

Lipset, Seymour Martin, Stein RokKan (1967): Cleavage Structures, Party Systems, and Voter Alignements: An Introduction; In Seymour 
Lipset, Stein Rokkan (eds.) Party Sytems and Voter Alignments. New York (Free Press), pp. 1-64

Stankov, Nemanja (2019): Springing up like Mushrooms after the Rain: „New“ Parties in Montenegro's Institutionalised Party System. Politics in Central Europe, Vol. 15, No. 1, pp. 163-185

SZABÓ ZsOlt (2021): Montenegró. In Halász Iván, Szabó Zsolt (szerk.) Alkotmány és kormányzás Kelet-Európában. Budapest, Gondolat Kiadó, Társadalomtudományi Kutatóközpont, Jogtudományi Intézete, 2021, 130-146. old.

TÓTH LÁSZLÓ (2020): A pártrendszerek átalakulásának és destabilizációjának hatása a kormányzati stabilitásra a 2010-es évek Európájában, THEMIS, az ELTE Állam- és Jogtudományi Doktori Iskolájának Folyóirata, 2020 május pp. 256-290.

Vujović, Zlatko, Nikoleta Tomović (2019): The Presidentialisation of Political Parties in Montenegro: A Limited Semi-presidentialism; In Gianluca Passarelli (ed.) The Presidentialisation of Political Parties in the Western Balkans. Palgrave Macmillan, pp. 119-144

Vuković, IVAN (2013): Political dynamics of the post-communist Montenegro: One-party show. Democratization, 2013, pp. 1-19

\section{Hivatalos dokumentumok, források}

MONTENEGRO'S CONSTITUTION OF 2007. Letöltés helye: https://www.constituteproject.org/constitution/Montenegro 2007.pdf (letöltve: 2021. október 9.)

PARLIAMENT OF MONTENEGRO: MP GROUPS. Letöltés helye: https://www.skupstina.me/en/mps/mp-groups (letöltve: 2021. október 9.)

\section{Újságcikkek}

BRÜCKNER GERGELY (2021): Egész. Európának súlyos figyelmeztetés Montenegró esete a kinaiak bitelével. https://telex.hu/gazdasag/2021/04/25/egesz-europanak-sulyosfigyelmeztetes-montenegro-esete-a-kinaiak-hitelevel (letöltve: 2021. október 9.)

Kajosević, SAmir (2020a): Montenegro Religious Protesters Step Up Rallies Abead of Polls. Balkan Insight. 
https://balkaninsight.com/2020/08/24/montenegro-religiousprotesters-step-up-rallies-ahead-of-polls/ (letöltve: 2021. október 9.) Kajosević, SAMIR (2020b): Montenegro Coalition Leaders Snipe at Expert Cabinet' Plan. Balkan Insight. https://balkaninsight.com/2020/11/03/montenegro-coalition-leaderssnipe-at-expert-cabinet-plan/ (letöltve: 2021. október 9.)

Kajosević, SAmir (2021a): Montenegro's New Authorities Move to Fire Special Prosecutor. Balkan Insight. https://balkaninsight.com/2021/02/03/montenegros-new-authoritiesmove-to-fire-special-prosecutor/ (letöltve: 2021. október 9.)

Kajosević, SAmir (2021b): Montenegro Delays Law Easing Citizenship Amid Opposition Protests. Balkan Insight. https://balkaninsight.com/2021/04/08/montenegro-delays-law-easingcitizenship-amid-opposition-protests/ (letöltve: 2021. október 10.)

Kajosević, SAmir (2021c): Montenegro to Sign Agreement With Serbian Orthodox Church. Balkan

Insight. https://balkaninsight.com/2021/04/19/montenegro-to-sign-agreementwith-serbian-orthodox-church/ (letöltve: 2021. október 9.)

Kajosević, SAmir (2021d): Montenegro State Prosecutor Steps Down After Law Changes. Balkan Insight. https://balkaninsight.com/2021/06/10/montenegro-state-prosecutorsteps-down-after-law-changes/ (letöltve: 2021. október 9.)

Kajosević, SAmir (2021e): Montenegro Govt in Crisis as Coalition Partner Announces Boycott. Balkan Insight. https://balkaninsight.com/2021/06/18/montenegro-govt-in-crisis-ascoalition-partner-announces-boycott/ (letöltve: 2021. október 9.)

Kajosević, SAmir (2021f): Reshuffle Demand Further Strains Montenegro's Fragile Govt. Balkan Insight. https://balkaninsight.com/2021/09/16/reshuffle-demand-furtherstrains-montenegros-fragile-govt/ (letöltve: 2021. október 9.)

KALUĐEROVIĆ, SNEŽANA (2021): Centralization of election and dismissal of school directors continues bad practice of the previous government. Centre for Civic Education. http://cgo-cce.org/en/2021/05/27/centralizacija-izbora-irazrjesenja-direktora-skola-nastavlja-losu-praksu-prethodnevlasti/\#.YWHsvhpBzcs (letöltve: 2021. október 9.)

Koseva, Denitsa (2021): Montenegro's parliament finally approves budget for 2021. BNE IntelliNews. https://intellinews.com/montenegro-s- 
parliament-finally-approves-budget-for-2021-213501/ (letöltve: 2021. október 9.)

LIKA, İDLIR (2021): Déjà vu: Assessing the recent political tensions in Montenegro. Anadolu Agency. https://www.aa.com.tr/en/analysis/opiniond $\%$ C3\%A $9 \% \% \mathrm{C} 3 \% \mathrm{~A} 0$-vu-assessing-the-recent-political-tensions-inmontenegro/2367173\# (letöltve: 2021. október 9.)

Milić, PRedrag (2020): Montenegro's parliament approves new, pro-Serb government. AP News. https://apnews.com/article/cabinets-serbiamontenegro-elections-parliamentary-elections26d056c4f3bc243f4d87c61001865fb5 (letöltve: 2021. október 9.)

MONTENEGRO CLASHES AS SERB ORTHODOX CHURCH LEADER INSTALLED. BBC. (2021) https://www.bbc.com/news/world-europe-58451372 (letöltve: 2021. október 9.)

LEPOSAVIC APPROVED THAT SPC DIOCESES IN MONTENEGRO EXISTED SINCE 1220. CDM. (2021) https://www.cdm.me/english/leposavicapproved-that-spc-dioceses-in-montenegro-existed-since-1220/ (letöltve: 2021. október 10.)

Montenegro: Tensions erupt over Serbian CHurch leaders. DW. (2021) $\quad$ https://www.dw.com/en/montenegro-tensions-erupt-overserbian-church-leaders/a-59087415 (letöltve: 2021. október 9.)

MONTENEGRO ADOPTS NEW LAW ON STATE PROSECUTION, SOME ELEMENTS REMAIN CONTROVERSIAL. European Western Balkans EWB. (2021)

https://europeanwesternbalkans.com/2021/05/12/montenegro-adoptsnew-law-on-state-prosecution-some-elements-remain-controverisal/ (letöltve: 2021. október 9.)

Montenegrin Parliament Opens Debate On New Cabinet. Radio Free Europe. (2020) https://www.rferl.org/a/30980267.html (letöltve: 2021. október 9.)

Herceg Novi: Uzlet Demokrata i pad Đukanovićeve DPS. Radio Slobodna Evropa. (2021) https://www.slobodnaevropa.org/amp/herceg-novi-uzlet-demokrata-ipad-\%C4\%91ukanovi\%C4\%87eve-dps/31247961.html (letöltve: 2021. október 9.)

THEY PROPOSED A PROCEDURE FOR THE DISMISSAL OF DJUKANOVIC. Radijo i Televizija Crne Gore - RTCG. (2021) http://www.rtcg.me/english/montenegro/334176/they-proposed-a- 
procedure-for-the-dismissal-of-djukanovic.html (letöltve: 2021. október 9.) 